Article

\title{
Consumers' Attitude toward Sustainable Food Products: Ingredients vs. Packaging
}

\author{
Soyoung Seo ${ }^{1}$, Hee-Kyung Ahn ${ }^{2}$, Jaeseok Jeong ${ }^{3}$ and Junghoon Moon ${ }^{1, *}$ \\ 1 Food Biz. Lab, Program in Regional Information, Seoul National University, Gwanak-gu 151-742, Korea; \\ sso34@snu.ac.kr \\ 2 School of Business, Hanyang University, 222 Wangsimni-ro, Seongdong-gu 133-791, Korea; \\ hkahn@hanyang.ac.kr \\ 3 Graduate School of Pan-Pacific International Studies, Kyung Hee University Global Campus, \\ Seochon-dong 17104, Korea; profjeong@khu.ac.kr \\ * Correspondence: moonj@snu.ac.kr; Tel.: +82-2-880-4722
}

Academic Editor: Thomas A. Trabold

Received: 29 August 2016; Accepted: 18 October 2016; Published: 22 October 2016

\begin{abstract}
The availability of and preference for eco-friendly products have increased; however, understanding of sustainable products is still insufficient because most studies have been focused only on organic products. The availability and understanding of organic products are high, but not complete. With regards to environmental protection, it is important to focus not only on the eco-friendly ingredients but also on the eco-friendly packaging because packaging has recently been found to be a primary cause of pollution. Through three studies, this article investigated the interaction between the effect of consumers' willingness to buy (WTB), the price premium for eco-friendliness (internal: eco-friendly ingredients vs. external: eco-friendly packaging), and the product's attributes. Three experimental studies were conducted to determine whether the consumers' WTB and the price premium for sustainable products differ according to the eco-friendliness of the product and the product's attributes. In Study 1 and Study 3, analysis of variance (ANOVA) was conducted; and, in Study 2, analysis of covariance (ANCOVA) was conducted. The results of Study 1 and Study 2 suggested that the consumers' WTB for sustainable products can differ according to the product's attribute. Moreover, results of Study 3 revealed that consumers' WTB and satisfaction for sustainable products can differ according to level of packaging.
\end{abstract}

Keywords: sustainable food product; organic food product; eco-friendly packaging; product attribute

\section{Introduction}

The market ratio of sustainable products is gradually increasing because environmental pollution has increased consumers' concerns related to morality [1] and a number of health scares and crises related to product safety. Due to these concerns (e.g., ethical issues and concerns for health), consumers have changed their behavior toward purchasing sustainable products. Many previous studies have shown that sustainable products have a competitive advantage over conventional products [2]. A product's sustainability, one type of information about the product, can be communicated to consumers via certification. Certification gives consumers confidence in the product's value or safety [3]. In the marketplace, we can find many kinds of certifications that indicate the sustainability of a product, especially for food products. Certifications of the sustainable attributes of sustainable food products can be divided into two parts [4]. One involves the products' internal sustainability (e.g., ingredient: organic, and Hazard Analysis and Critical Control Point-HACCP) while the second involves the products' external sustainability (e.g., Fairtrade, and eco-friendly package). Eco-friendly products occupy most of the sustainable product market place [5]. For this reasons, many companies 
make effort to distribute eco-friendly products. There are two typical and discrete methods of producing eco-friendly products: one is to make the product with eco-friendly ingredients and the other is to pack the product with eco-friendly packaging. Most producers supply eco-friendly products by using only one of the aforementioned methods, even though both of methods can be used. This is because of the production cost and the possibility that using eco-friendly components can change the product's central traits like taste or other properties.

The eco-friendliness of eco-friendly ingredients is an internal attribute of product, as the eco-friendly ingredient is directly related to product itself. Most well-known eco-friendly ingredients are in organic products [6]. Cognitively, consumers consider organic products beneficial and gentle for the environment and for health [7-9]. This perception contributes to the added value of products, particularly food. Along these lines, many studies have explored the effect of organic products on consumers' purchasing behavior [10,11]. In a previous study, organic information was found to increase consumer's product evaluation more than conventional information, even if the products were the same [12]. However, other previous findings have suggested that organic products are not always evaluated higher than conventional products [13-16]. This shows that the expectation for organic information can negatively affect the expectations for the product.

The eco-friendliness of eco-friendly packaging is an external attribute of the product, as packaging is an external element of product. Packaging is an indispensable element for sales [17]. In recent years, however, packaging has been noted to be a cause of pollution; thus, the necessity for eco-friendly packaging is gradually growing $[18,19]$. Previous studies have shown that consumers prefer eco-friendly packed products over conventional products $[4,19,20]$. Through previous studies we can see that the eco-friendliness of packaging makes products more valuable. Nevertheless, there are a few kinds of eco-friendly packaged products in the marketplace, and few studies have dealt with consumers' attitude toward such products. Therefore, it is necessary to pay more attention to consumers' preference for eco-friendly packaged products.

Another method to prevent the environment pollution caused by packaging is to use appropriate packaging. Consumers consider avoiding excessive packaged products as having more environmental benefits than other ecological food consumption, whereas they consider buying organic products as the least environmentally beneficial option [21]. Packaging is the first element of a product consumers encounter before making their purchasing decision [22]. The visual signals (e.g., size, color, and shape) of packages primarily affect consumers' product evaluation $[23,24]$. Therefore, we can hypothesize that consumers primarily evaluate products' sustainability via the level of packaging (appropriate vs. excessive).

Most existing studies have only focused on consumers' preferences for organic food products, which are made with eco-friendly ingredients, and the understanding of consumers' preference for eco-friendly food products remains limited. In addition, previous researchers have not investigated whether the eco-friendly packaged products have a comparative advantage over eco-friendly ingredient products. Moreover, investigations into whether consumers' attitude towards eco-friendly products differs according to the level of packaging (appropriate vs. excessive) have not been conducted. In this study, through comparative studies of the eco-friendliness and product attributes regarding consumers' purchase intentions, we investigated the effectiveness of imposing eco-friendly packaging to products when products' attributes and the expectation for eco-friendly ingredients are not consistent.

In Studies 1 and 2, there are identical products with two different types of eco-friendliness that were given to each independent group. One of the products has a different attribute (e.g., hedonic vs. utilitarian). In Figure 1, we examined the interaction effect between products' attributes and eco-friendliness (Internal: eco-friendly ingredient vs. External: eco-friendly packaging) by examining the subjects' willingness to buy (WTB) and the price premium, to highlight the importance of using proper sustainable attributes according to products' attributes. 
Independent Variables

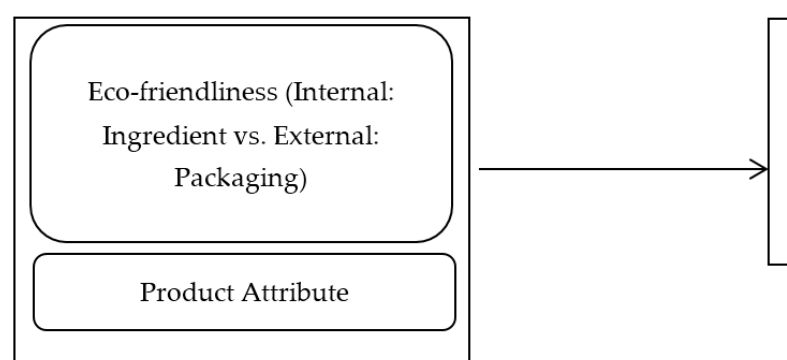

Dependent Variables

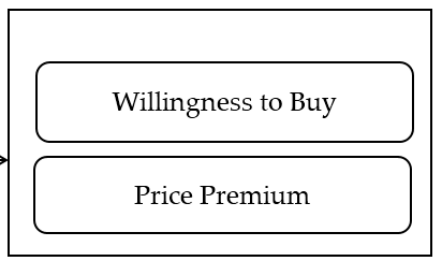

Figure 1. Research model of Studies 1 and 2; interaction effect between sustainable attributes and product attributes.

In Study 3 (Figure 2), through an actual taste-evaluating experiment, we investigated whether consumers' attitude toward eco-friendly products can differ according to the level of packaging (appropriate vs. excessive); the importance of using proper packaging material was highlighted. Similar to Studies 1 and 2, we assessed the interaction effect between eco-friendliness (Internal: eco-friendly ingredient vs. External: eco-friendly packaging) and the level of packaging (appropriate vs. exaggerated). At the end of this research, we conclude with a discussion of the theoretical and managerial implications of the findings.

Independent Variables

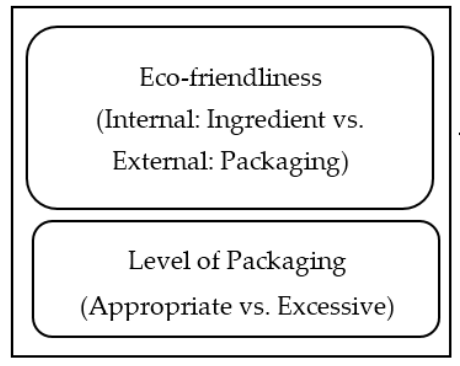

Dependent Variables

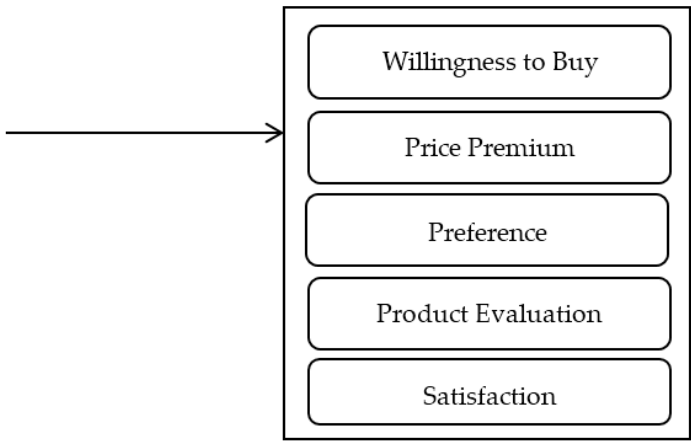

Figure 2. Research model of Study 3; interaction effect between eco-friendliness and the level of packaging.

\section{Theoretical Background and Hypothesis}

Most consumers have a positive attitude toward purchasing organic food products, and some purchase organic products on a regular basis [8]. The definition of organic production is not uniform across all products [25], and thus it is difficult to precisely define organic food products. The United States Department of Agriculture (USDA) defines organic production as a production system that avoids, or largely excludes, the use of synthetic chemicals and does not incorporate genetically modified products [26]. Consumers link these attributes of organic products to healthiness, and therefore consumers prefer food products that provide information about the organic aspect [7-9]. According to a previous study [25], the definition of a sustainable product is unclear and it is not clearly defined whether organic products are sustainable or not; however, cognitively, consumers consider an organic food product that certified its internal eco-friendliness as more eco-friendly than conventionally produced food products. Traditionally, organic products have been recognized as beneficial not only for the environment, but also for personal health [7-9]. Therefore, consumers consider organic products to be reputable products [6], and they expect organic products to be healthy and environmentally friendly. Sörqvist et al. [12] found that even if the ingredients in coffee are the same, subjects exhibited 
a higher purchase intention and sensory evaluation to one kind of coffee when they were informed that it was organic. This means that consumers have expectations for the organic information and this added positively to their expectations for the conventional product. However, previous studies have suggested that organic products are not always evaluated more highly than conventional products [13-15]. Lee et al. [14] found that consumers give a higher taste evaluation for organic yogurts than for conventional yogurts, however, they found that consumers give a lower taste evaluation for organic cookies than regular ones. Luchs et al. [13] found that organic products are not always preferred. They estimated consumers' intention to purchase organic products (vs. conventional products), such as baby shampoo and car wash shampoo, the attributes of which are related to gentleness and strength, respectively. As a result, they found that consumers have a tendency to evaluate their preference for sustainable products as lower than their preference for conventional products when the product's attribute is related to strength (vs. gentleness). This is because organic products made with eco-friendly ingredients are perceived as less effective by consumers [16]. In summary, the eco-friendliness of an organic product-internal attribute-is directly related to the product itself; however, this can be a negative or positive factor according to the product's attributes.

Another aspect of sustainable food products is that they exist in the marketplace as products with eco-friendly packaging. Because packaging is an extrinsic element of products, it does not affect the products themselves [27]; therefore, the eco-friendliness of packaging is not directly related to a product itself. According to Svanes et al. [28], eco-friendly packaging can be described as packaging that has the general functions of a package, produced with eco-friendly materials (made with minimal recyclable and biodegradable materials), and is economically sustainable. The general functions of packaging are as follows. Packaging prevents damage that can occur during distribution [29]. Packaging is an indispensable element in product sales because it gives specific information about a product [30]. Packaging catches the consumer's eye, and it can affect the consumer's purchase intentions. Packaging has an impact on consumers' evaluation of the product; when packaging is well made, it can elicit a positive evaluation of a product. According to Rokka and Uusitalo [19], eco-friendly packaging was the second priority for consumers, while the first priority was product functionality. Magnier and Schhormans [20] found that the visual and verbal cues of packages' sustainability foster significant environmental concerns, as consumers' intentions were to purchase sustainable food products. Magnier et al. [4] also found that whether a product is considered a healthy food (raisins) or an unhealthy food (chocolate bar), the perceived quality of an eco-friendly packaged product was higher than a conventionally packed product. This presupposes that eco-friendly packaging has benefits that increase a product's value. Through previous studies, we can notice that eco-friendly packaging does not affect a product's attributes, therefore it does not have a direct influence on product evaluation, however, this factor positively and indirectly influences the overall evaluation.

In summary, two types of eco-friendly products (eco-friendly ingredient product vs. eco-friendly packaging product) have different attributes; the eco-friendliness of an eco-friendly ingredient product is an internal attribute. The expectations for eco-friendly ingredient products are directly related to the consumers' expectations for conventional products. When the expectations for eco-friendly ingredient products and expectations for conventional products are inconsistent, an expectancy disconfirmation [31] occurs. Consumers' preference for eco-friendly ingredient products will be lower than the preferences for conventional products. Unlike eco-friendly ingredient products, the eco-friendliness of eco-friendly packaging is an external attribute. The expectations for eco-friendly packaging indirectly relates to the consumers' expectations for the conventional products. Therefore, the expectations for eco-friendly packaging do not affect the expectations for conventional products.

Food becomes a part of the body after it is ingested. Therefore, consumers have a tendency to focus on the healthfulness of food when they are eating it [32]. Consumers also focus on a food's hedonic characteristics. Food products can be distinguished as either utilitarian or hedonic. Consumers have expectations of utilitarian food products to be healthful, functional, and energetic, while they expect hedonic foods to be delicious and enjoyable [33]. Utilitarian food products are consumed for cognitive 
and functional purposes [34]. These purposes are similar to the purposes of consuming an organic food product, and the expectations of organic products are also congruent with utilitarian expectations. Thus, according to expectancy confirmation theory [31], it can be predicted that consumers will have a higher WTB for organic utilitarian food products than for eco-friendly packaged ones. Chocolate chip cookies, for example, tend to be an example of a hedonic food product, consumed based on their taste, texture, and visual beauty [35]. Consumers regard organic chocolate chip cookies as less tasty than conventional ones [14]. According to Magnier et al. [4], consumers preferred the eco-friendly packed chocolate bar which is strongly related to hedonic than conventional. According to the previous studies, we can hypothesize that when the expectations for products are congruent with the expectations for eco-friendly ingredient, consumers will prefer eco-friendly ingredient products over eco-friendly packaged products because generally consumers have higher preference for eco-friendly ingredient products. However, when the expectations are incongruent, they will prefer the conventional products. Consequently, their preference for each product will be linked to their willingness buy (WTB) and the price premium $[36,37]$. Therefore, consumers' WTB and the price premium will be higher with the eco-friendly ingredient utilitarian products than the eco-friendly packaged utilitarian products because the expectations for utilitarian products are congruent with the expectations for eco-friendly ingredient products. Meanwhile, expectations for the hedonic products are incongruent with the expectations for the eco-friendly ingredient products, therefore the preference for eco-friendly ingredient hedonic products will be lower than the preference for eco-friendly packed hedonic products, because in previous study, eco-friendly packed products were evaluated as more attractive than conventional ones. Therefore, Hypothesis 1 and Hypothesis 2 were established as follows:

H1: Consumers' WTB and price premium are higher for products with eco-friendly ingredients (vs. eco-friendly packaging) when a product is utilitarian.

H2: Consumers' WTB and price premium are higher for products with eco-friendly packaging (vs. eco-friendly ingredients) when a product is hedonic.

Consumers also have different cognitive expectations for products according to their attributes. According to Luchs et al. [13], consumers expect a product whose attributes are related to gentleness to be safe, healthy, good for children, and mild. In contrast, they expect a product whose attributes are related to strength to be strong, powerful, tough, effective, and get the job done. Based on these previous studies, we can assume that consumers' WTB for eco-friendly ingredient products is higher (vs. eco-friendly packaged products) in instances in which the products' attributes are related to gentleness (vs. strength). On the contrary, however, consumers' WTB for eco-friendly packaged product (vs. eco-friendly ingredient product) is higher in cases in which the products' attributes are related to strength (vs. gentleness) because of expectancy disconfirmation. Accordingly, we formulated the following hypotheses:

H3: Consumers' WTB and price premium are higher for products with eco-friendly ingredients (vs. eco-friendly packaging) when a product's attributes are related to gentleness.

H4: Consumers' WTB and price premium are higher for products with eco-friendly packaging (vs. eco-friendly ingredients) when a product's attributes are related to strength.

Packaging can be categorized into three types: primary packaging, secondary packaging, and tertiary packaging [17]. As seen in snack packaging, primary packaging contains only the product, whereas secondary packaging contains the primary packaging. Secondary packaging may be discarded immediately when consumers use the product. Finally, tertiary packaging is used for bulk handling and warehouse storage. Food packaging has two characteristics: it contains the product and it is thrown away immediately after the food product has been consumed. Currently, about $50 \%$ of discarded packaging is food packaging [29]. For environmental reasons, it is necessary to reduce the disposal of food packaging. Therefore, the ness to use eco-friendly packaging is growing worldwide. However, the use of eco-friendly packaging increases production costs. Therefore, a basic method to 
prevent the environmental pollution that can be caused by packaging is to use appropriate packaging. According to Tobler et al. [21], consumers regard the avoidance of excessive-packaged products as the most environmentally beneficial, even greater than other ecological food consumption, whereas they consider buying organic products the least environmentally beneficial. Packaging is the first element encountered when consumers see a product before making their decision [22]. The visual signals (size, color, and shape) of the package primarily affect consumers' product evaluation [23]. Accordingly, we can assume that consumers primarily evaluate a product's eco-friendliness on the level of packaging, whether it is packaged excessively or not. However, in some cases, the high prices of organic products and the attitude to maximize profits leads to excessive packaging, which appears to contain a lot of content. This can generate expectancy disconfirmation [31], as excessive packaging is not considered environmentally friendly. Meanwhile, following the property of products, the use of buffer packaging to protect the products from damage is needed. However, because consumers view excessive packaging negatively, consumers evaluate the buffer packaged products negatively. However, the information that buffer packaged products are made with eco-friendly packaging can prevent consumers' negative evaluation of them.

In summary, regarding purchase intention, eco-friendly ingredient products are judged less favorably when packaged with excessive packaging because of expectancy disconfirmation, consumers link high ethical standards to organic products; therefore, exaggerated packaging will be evaluated more negatively than appropriately packed organic products. However, when a product with eco-friendly packaging is packed in an exaggerated manner, cognitive dissonance [38] occurs. Consumers evaluate an exaggeratedly packed eco-friendly packaged product more highly than an appropriately packed one. Eventually, these evaluations will link to WTB and the price premium, based on this, Hypothesis 5 and Hypothesis 6 were established as follows:

H5: Consumers' preference, product evaluation, satisfaction, WTB, and price premium are higher for cookies packed in an appropriate manner (vs. exaggerated manner) when they are organic cookies.

H6: Consumers' preference, product evaluation, satisfaction, WTB, and price premium are higher for cookies packed in an exaggerated manner (vs. appropriate manner) when they are packed in eco-friendly packaging.

\section{Study 1: Comparative Study of the Eco-Friendliness and Product Attributes Regarding Consumers' Purchase Intentions: Utilitarian vs. Hedonic}

\subsection{Pretest}

Following Voss et al. [39], consumers' perception of stimuli's (utilitarian-protein bar vs. hedonic-jelly beans) attributes was estimated with a five-point Likert scale. We randomly selected 57 undergraduate students to participate in one of the two categories. Participants were recruited via online recruitment system. They rated the importance of each characteristic (utilitarian: protein bar vs. hedonic: jelly bean). The utilitarian attributes were estimated by "effective," "helpful," "functional," "necessary," and "practical" ( $\alpha=0.918)$. The hedonic attributes were estimated by "fun," "exciting," "delightful," "thrilling," and "enjoyable" ( $\alpha=0.943)$. As expected, the utilitarian attributes were more important for protein bars (Mean Difference utilitarian-hedonic $=1.389, p<0.001$ ) and the hedonic attributes were more important for jelly beans (Mean Difference utilitarian-hedonic $=-1.289, p<0.05$ ).

\subsection{Methods and Results}

In Study 1, a $2 \times 2$ between-subjects design was employed to test H1 and H2 (Figure 3). Through an online experiment, we investigated the interaction effect between eco-friendliness (Internal: eco-friendly ingredients-organic vs. External: eco-friendly packaging-green packaging) and the products' attributes (utilitarian: protein bar vs. hedonic: jelly bean). We manipulated the products' sustainable attributes with two kinds of certifications: one certification for eco-friendly ingredients, which certified their internal eco-friendliness (organic certification), and the other for eco-friendly 
packaging, which certified their external eco-friendliness (green packaging). The product package's sustainability can inform not only certification, but also its appearance such as a recycled cardboard appearance; however, if the package's material is not the same, there is possibility that consumers can perceive the same products as different products as the elements of packaging (e.g., color, and appearance) construct a product's identity. Therefore, in this study, we controlled the possibility that could occur from the different appearance of packaging and investigated the effect of the information provided through certification, by using green packaging certification which is one certification that Korea's national organization supports.

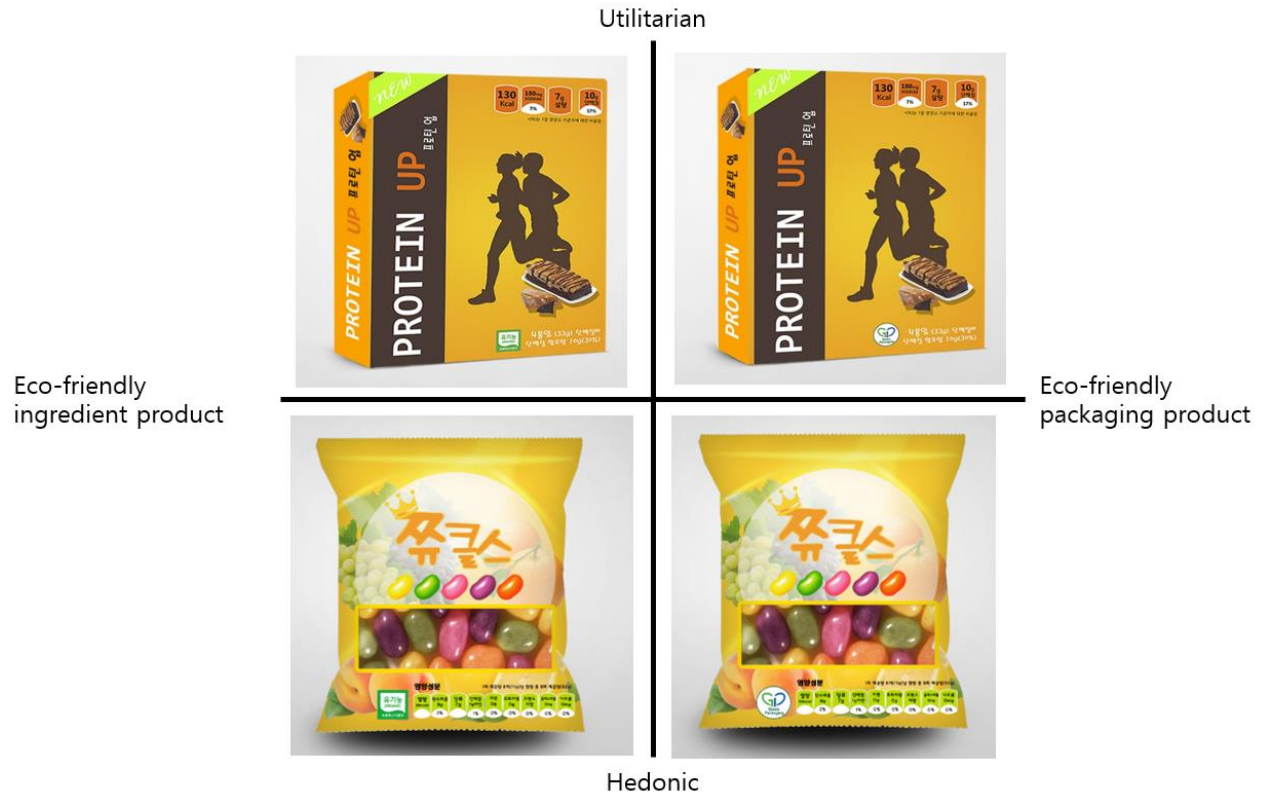

Figure 3. Experimental design of Study 1.

We informed subjects of products' characteristics: that they are new products that will be released by an anonymous company to prevent the bias that can arise from brand preference. In addition, we informed subjects of the products' sustainable attributes not just with these certifications, but also with the phrases: "It is an organic protein bar-(jelly bean) that is certified, and it is good for environmental protection" and "It is a green packaged protein bar-(jelly bean) that is certified, and it is good for environmental protection." To prevent external influences on consumers' purchase intention, the jelly bean packaging had a partially transparent design to show that it contained a variety of jelly beans. Moreover, participants rated the utilitarian and hedonic scales of the products [34]. Subjects answered the following questions: "To what extent do you think this product is utilitarian?" and "To what extent do you think this product is hedonic?" In addition, of note, they reported their weekly average frequency of jelly bean (or candy) intake.

Dependent variables are WTB [36] and the price premium (the average price of market \pm price premium) [37]. Four questions (WTB1-WTB4) were used to estimate the WTB (four items). The four items of WTB were: "It is likely that I will purchase this product"; "If I were going to buy this product, I would consider buying the product at the price shown"; "The probability that I would consider buying the product is high"; and "My willingness to buy the product is high." In addition, according to Cheng's [5] study, subjects' attitudes toward the environment in their daily lives were investigated because these attitudes are closely related to consumers' decision to buy sustainable products. Therefore, Ecologically Conscious Consumer Behavior (ECCB) measured whether or not individuals tended to have an environmentally friendly attitude on a daily basis [40]. The original version of ECCB consists of 30 measures. However, since too many questions can distract response veracity, we chose five questions (ECCB1-ECCB5), which are representative and culturally suitable. 
Measures for ECCB are the following: "I will not buy products which have elaborate packaging"; "When there is a choice, I always choose the product which contributes to the least amount of pollution"; "If I understand the potential damage to the environment that some products can cause, I do not purchase these products"; "I make every effort to buy paper products made from recycled paper"; and "Whenever possible, I buy products packaged in reusable containers." This provided a control for the study. WTB and ECCB were measured on a seven-point Likert scale ranging from 1 ("Strongly Disagree") to 7 ("Strongly Agree").

There were 240 (93 male and 147 female) people randomly chosen to participate in Study 1. Subjects were gathered through social networking sites since they are efficient channels for snowball sampling. The participants' ages ranged from twenties to fifties; most of them were in their twenties (152 in their twenties, 33 in their thirties, 42 in their forties, 13 in their fifties). Most were college graduates (71 with a high school diploma, 89 college graduates, 77 graduate students (or higher), 3 reported other), but there was a variety in education level.

In Study 1, according to the previous study [41], education level can influence the selection of eco-friendly products, and thus we set education level as the covariate. We assessed whether education level varied by conducting analysis of variance (ANOVA) and found no significant difference among the four groups $(F(1,236)=0.028, p=0.867)$. Therefore, we conducted two-way ANOVA in Study 1 .

Before conducting two-way ANOVA, we confirmed the convergent validity and the discriminant validity. To confirm the convergent validity, we checked the reliability of individual items and the construct reliability. According to Chin [42], the reliability of individual measures is ensured if the factor loading is higher than 0.7, and according to Fornell and Larker [41], if the average variance extracted (AVE) is greater than 0.5. If the square root of the AVE of each construct is greater than its correlation with the other constructs, the convergent validity is sufficient [41,43]. The results of convergent validities are seen in Table 1 ; the factor loadings of all measures are greater than 0.7 and the AVE scores for all variables are greater than 0.5. As shown in Table 2, the square roots of the AVEs are greater than the correlation between constructors. The measurement model demonstrates sufficient convergent validity and discriminant validity.

Table 1. The results of the convergent validities: Loadings among measures.

\begin{tabular}{ccccccc}
\hline Latent Variables & Items & $\begin{array}{c}\text { Factor } \\
\text { Loading }\end{array}$ & $\begin{array}{c}\text { Standard } \\
\text { Error }\end{array}$ & t-Statistic & $\begin{array}{c}\text { Composite } \\
\text { Reliability }\end{array}$ & AVE \\
\hline & WTB1 & 0.873 & 0.021 & 42.463 & 0.903 & 0.701 \\
Willingness to Buy & WTB2 & 0.824 & 0.024 & 34.953 & & \\
(WTB) & WTB3 & 0.897 & 0.019 & 46.333 & & \\
& WTB4 & 0.747 & 0.040 & 18.904 & & 0.585 \\
Ecologically & ECCB2 & 0.808 & 0.023 & 34.686 & 0.848 & \\
Conscious & ECCB3 & 0.620 & 0.064 & 9.7441 & & \\
Consumer & ECCB4 & 0.837 & 0.019 & 44.082 & & \\
Behavior (ECCB) & ECCB5 & 0.776 & 0.024 & 32.981 & & \\
\hline
\end{tabular}

Table 2. The results of the convergent validities: Correlation among constructs.

\begin{tabular}{ccc}
\hline Constructs & WTB & ECCB \\
\hline $\begin{array}{c}\text { Willingness to Buy (WTB) } \\
\text { Ecologically Conscious Consumer } \\
\text { Behavior (ECCB) }\end{array}$ & $\mathbf{0 . 8 3 7}$ & \\
\hline
\end{tabular}

On average, participants buy protein bars 0.394 times a week (among 114 participants) and they buy jelly beans 0.891 times a week (among 124 participants). They perceive protein bars to be more utilitarian (Mean Difference $=0.407, p<0.001$ ) and perceive jelly beans to be more hedonic (Mean Difference $=0.439, p<0.001$ ). 
As mentioned above, two-way ANOVA was conducted. The ECCB rate was controlled among the groups $(F=0.002, p=0.963)$; there were no existing differences. As shown in Table 3, there was no significant interaction effect on WTB $(F(1,236)=1.790, p=0.182)$ and price premium $(F(1,234)=2.083$, $p=0.149$ ). However, in the pairwise comparison (including a Bonferroni test), there was significant difference for jelly beans (hedonic product). Subjects rated WTB higher for eco-friendly packaged jelly beans $(\mathrm{N}=65, \mathrm{M}=3.185, \mathrm{SD}=0.815)$ than eco-friendly ingredient jelly beans $(\mathrm{N}=61, \mathrm{M}=2.877$, $\mathrm{SD}=0.858)(F(1,236)=4.551, p=0.034)$. However, for protein bars, there was no significant difference; subjects did not rate WTB for eco-friendly ingredient protein bars $(\mathrm{N}=61, \mathrm{M}=3.119, \mathrm{SD}=0.729)$ higher than eco-friendly packaged protein bars $(\mathrm{N}=53, \mathrm{M}=3.146, \mathrm{SD}=0.828)(F(1,236)=0.032, p=0.857)$. $\mathrm{H} 2$ for WTB was partially accepted.

Table 3. ANOVA results of Study 1: Willingness to Buy (WTB).

\begin{tabular}{cccc}
\hline Source & df & $\boldsymbol{F}$ & $\boldsymbol{p}$ \\
\hline Intercept & 1 & 3465.153 & 0.000 \\
Product attributes & 1 & 0.944 & 0.332 \\
Sustainable attributes & 1 & 2.558 & 0.111 \\
Product attributes $\times$ Sustainable attributes & 1 & 1.790 & 0.182 \\
Corrected model & 3 & 1.808 & 0.146 \\
\hline
\end{tabular}

\section{Study 2: Comparative Study of the Sustainable Attributes and Product Attributes Regarding Consumers' Purchase Intentions: Gentleness vs. Strength}

\subsection{Pretest}

Following Luchs et al. [13], consumers' perception of stimuli's (yogurt vs. energy drink) attributes was evaluated with a five-point Likert scale. We randomly selected 61 undergraduate students who were gathered through an online recruitment system to participate in one of the two categories. They rated how important each of the characteristics (gentleness vs. strength) was when buying yogurt (vs. energy drinks) ranging from 1 (not very important) to 5 (very important). The gentleness attribute factors included "gentle," "safe," "healthy," "mild," and "good for children" $(\alpha=0.815)$. Strength attribute factors were "strong," "powerful," "tough," "effective," and "gets the job done" $(\alpha=0.841)$. As expected, the gentleness attributes were more important for yogurt (Mean Difference gentleness-strength $=1.129, p<0.001)$. On the contrary, the strength attributes were more important for energy drinks (Mean Difference gentleness-strength $=-0.253, p>0.05$ ).

\subsection{Methods and Results}

Based on Luchs et al. [13], in Study 2, as in Study 1, a $2 \times 2$ between-subjects design was employed to explore $\mathrm{H} 3$ and $\mathrm{H} 4$. Through an online experiment, we investigated the interaction effect between sustainable attributes (Internal: eco-friendly ingredients-organic vs. External: eco-friendly packaging-green packaging) and product attributes (gentleness-related products: yogurt vs. strength-related products: energy drink).

As in Study 1, we manipulated the products' eco-friendliness using two kinds of certifications and phrases. We also informed the subjects of the product's characteristics as done in Study 1. To prevent external influences on consumers' purchase intention arising from the products' taste, subjects were informed that many kinds of yogurt flavors would be released. Four independent groups of participants took one of the stimuli (Figure 4) and as in study 1, they evaluated their WTB and price premium, in addition to their ECCB rating (a seven-point Likert scale).

There were 302 (159 male, 137 female, and 6 unreported) people randomly chosen to participate from an online source. We also gathered subjects through social networking sites for snowball sampling. Participants' ages ranged from twenties to sixties; most of them were in their twenties (183 in their twenties, 55 in their thirties, 42 in their forties, 12 in their fifties, 4 in their sixties, and 
6 unreported). Furthermore, most of them were college graduates ( 2 with a middle school diploma, 78 with a high school diploma, 141 college graduates, 72 graduate students [or higher], 3 reported other, and 6 unreported). The four independent groups of participants evaluated one of the products, respectively (Figure 4).

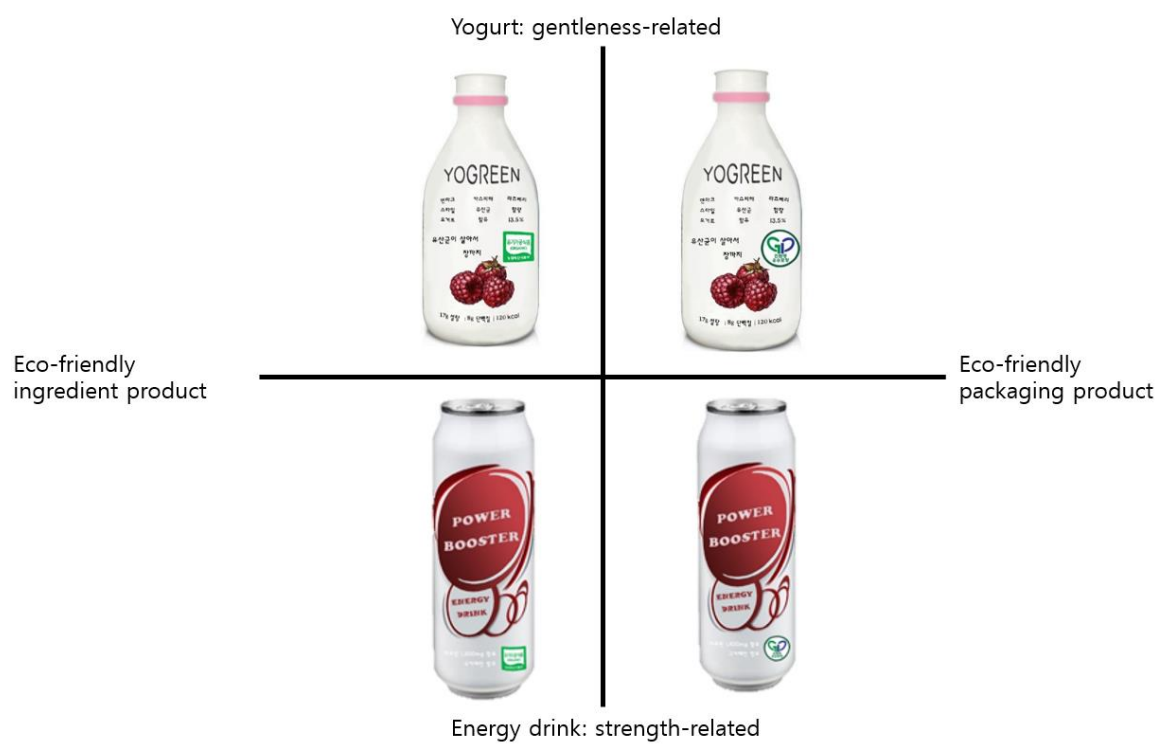

Figure 4. Experimental design of Study 2.

According to a previous study [43], we also assessed whether education level varied by conducting ANOVA and found a significant difference among the four groups at the 0.1 level $(F(1,292)=3.383$, $p=0.067)$. Therefore, we set education level as covariance and we conducted two-way analysis of covariance (ANCOVA) in Study 2.

Before conducting two-way ANCOVA, we also confirmed the convergent validity and the discriminant validity of constructs. As shown in Table 4, all the factor loadings of measures are greater than 0.7, and the AVE scores for all variables are greater than 0.5. As shown in Table 5, the square roots of the AVEs are greater than the correlation between constructors. Therefore, our measurement model demonstrates sufficient convergent validity and discriminant validity.

Table 4. The results of the convergent validities: Loadings of the measures.

\begin{tabular}{ccccccc}
\hline Latent Variables & Items & $\begin{array}{c}\text { Factor } \\
\text { Loading }\end{array}$ & $\begin{array}{c}\text { Standard } \\
\text { Error }\end{array}$ & $t$-Statistic & $\begin{array}{c}\text { Composite } \\
\text { Reliability }\end{array}$ & AVE \\
\hline & WTB1 & 0.893 & 0.014 & 62.059 & 0.924 & 0.752 \\
Willingness to Buy & WTB2 & 0.857 & 0.017 & 50.308 & & \\
(WTB) & WTB3 & 0.925 & 0.010 & 97.614 & & \\
& WTB4 & 0.789 & 0.023 & 34.474 & & 0.625 \\
Ecologically & ECCB2 & 0.791 & 0.021 & 37.551 & 0.869 & \\
Conscious & ECCB3 & 0.722 & 0.035 & 20.411 & & \\
Consumer Behavior & ECCB4 & 0.866 & 0.016 & 55.779 & & \\
(ECCB) & ECCB5 & 0.776 & 0.026 & 29.609 & & \\
\hline
\end{tabular}

After the convergent and discriminant validity tests, two-way ANCOVA was conducted. The ECCB rate did not vary among the groups $(F=0.506, p=0.477)$; there were no existing differences: it was controlled. As we had expected on WTB (Table 6), a significant interaction effect (Figure 5) exists between sustainability attributes and product attributes $\left(F(1,291)=4.095, p=0.044^{2}\right)$; however, the price premium was not significant $\left(F(1,286)=0.436, p=0.510^{2}\right)$. 
Table 5. The results of the convergent validities: Correlation among constructs.

\begin{tabular}{ccc}
\hline Constructs & WTB & ECCB \\
\hline $\begin{array}{c}\text { Willingness to Buy (WTB) } \\
\text { Ecologically Conscious Consumer } \\
\text { Behavior (ECCB) }\end{array}$ & $\mathbf{0 . 8 6 7}$ & \\
\hline
\end{tabular}

Note: Square roots of AVEs are in bold.

Table 6. ANCOVA results of Study 2: WTB.

\begin{tabular}{cccc}
\hline Source & df & $\boldsymbol{F}$ & $\boldsymbol{p}$ \\
\hline Intercept & 1 & 169.484 & 0.000 \\
Education & 1 & 1.813 & 0.179 \\
Product attributes & 1 & 2.8 & 0.095 \\
Sustainable attributes & 1 & 0.574 & 0.449 \\
Product attributes $\times$ Sustainable attributes & 1 & 4.095 & 0.044 \\
Corrected model & 4 & 2.186 & 0.071 \\
\hline
\end{tabular}

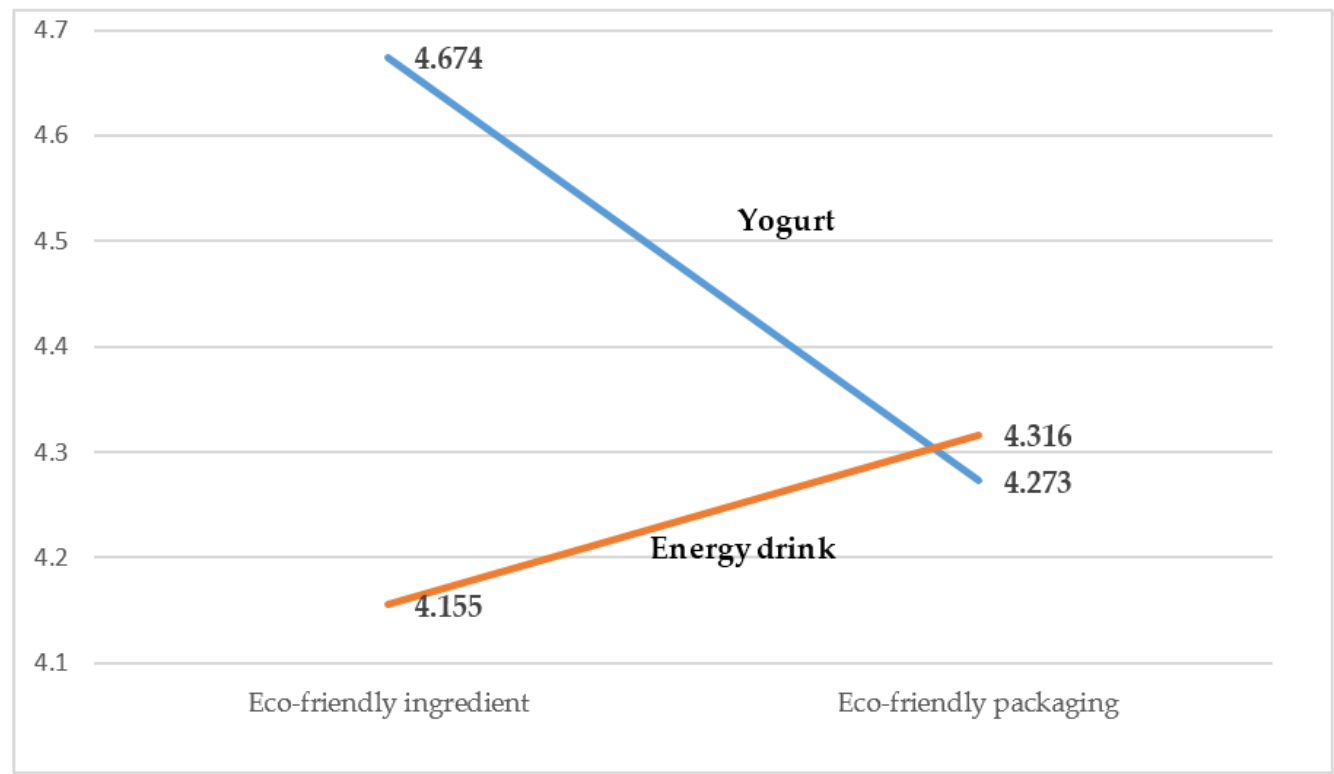

Figure 5. Results of Study 2: Willingness to Buy (WTB).

After two-way ANCOVA, we also conducted pairwise comparison (including a Bonferroni test) using WTB, and checked the differences among groups. With yogurt $(F(1,291)=3.945, p=0.048)$, eco-friendly ingredients $(\mathrm{N}=76, \mathrm{M}=4.674, \mathrm{SD}=1.109)$ led to a higher WTB than eco-friendly packaging $(\mathrm{N}=74, \mathrm{M}=4.273 \mathrm{SD}=1.189)$. However, for energy drinks $(F(1,291)=0.796, p=0.373)$, sustainability attributes had no significant effect. Nonetheless, eco-friendly packaging $(\mathrm{N}=72$, $\mathrm{M}=-4.316, \mathrm{SD}=1.306)$ received a higher score on the WTB than eco-friendly ingredients $(\mathrm{N}=74$, $\mathrm{M}=-4.155, \mathrm{SD}=1.475)$. The results supported our hypothesis regarding $\mathrm{WTB}(\mathrm{H} 3)$, but not $\mathrm{H} 4$, and the findings suggest that WTB for sustainable products can differ according to sustainability attributes and product attributes.

\section{Study 3: Comparative Studies of the Sustainable Attributes and Levels of Packaging Regarding Consumers' Purchase Intentions: Appropriate vs. Exaggerated}

In Study 3, through a laboratory experiment, we investigated the consumers' actual evaluations of sustainable products. In South Korea, most products with exaggerated packaging are cookies or snacks. Therefore, we used chocolate chip cookies as a stimulus. 


\subsection{Pretest}

We investigated consumers' recognition of the packaging level, appropriate packaging vs. exaggerated packaging, to check whether subjects can cognize the excessiveness of exaggerated packaging. We randomly selected 50 undergraduate students to participate in one of two categories (between-subjects design; 25 subjects each). In addition, they were recruited via online recruitment system. They rated how excessive the packaging level was (by a five-point Likert scale; one questionnaire). As expected, they evaluated exaggerated packaging as more excessive than appropriate packaging (Mean Difference exaggerate-appropriate $=0.68, p<0.015$ ).

\subsection{Methods and Results}

Using a $2 \times 2$ between-subjects design, we investigated the interaction effect between two types of eco-friendliness (Internal: eco-friendly ingredients-organic vs. External: eco-friendly packaging-green packaging) and two levels of packaging (appropriate vs. exaggerated) (Figure 6).

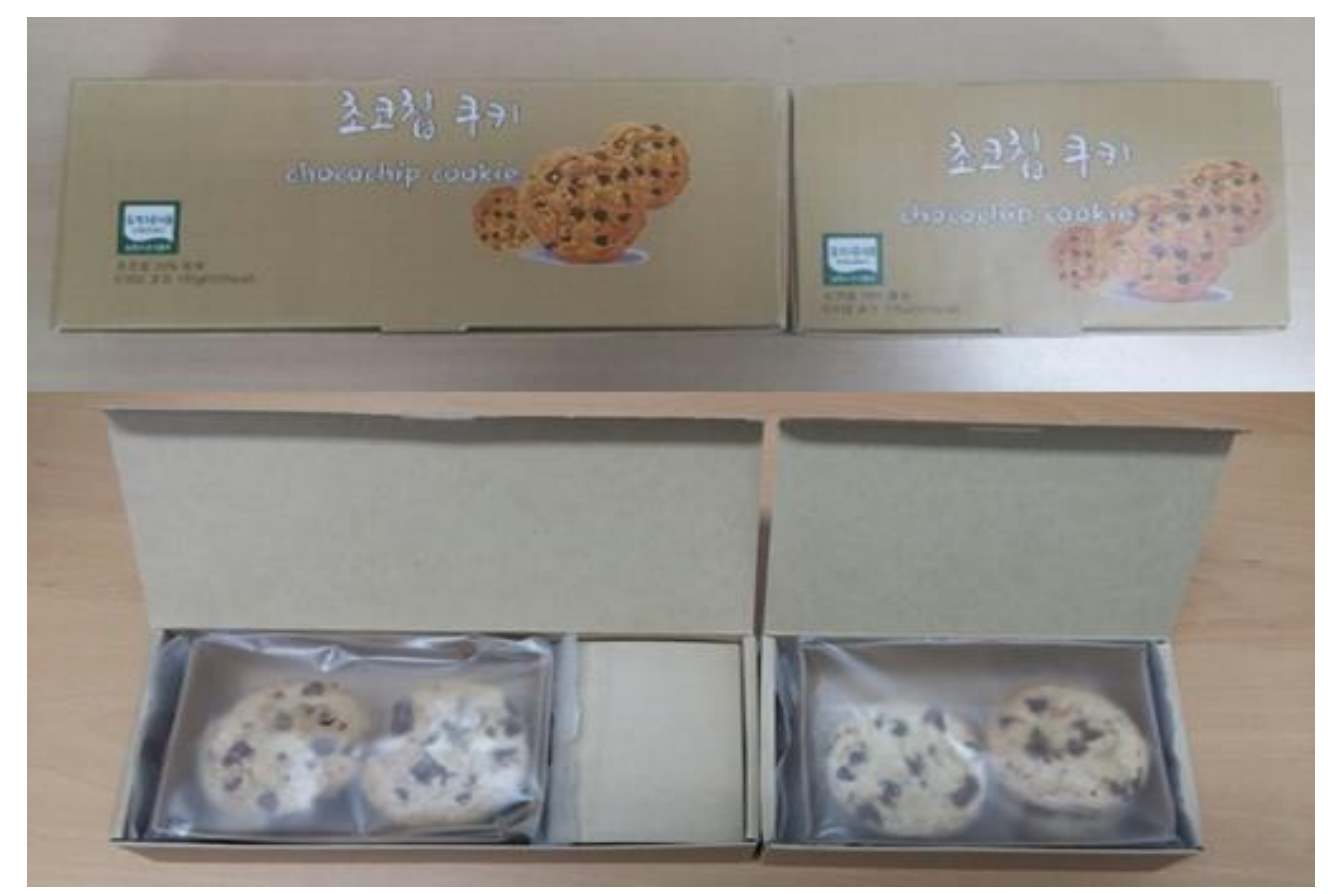

Figure 6. Study 3 Stimuli (Cookies on the left: exaggerated packaging; on the right: appropriate packaging).

Subjects were undergraduate students in Seoul National University and Hanyang University. They were recruited through help-wanted advertisements that were posted on an online bulletin. Subjects received one package of chocolate chip cookies (Figure 7) containing six cookies. Following Studies 1 and 2, we informed each group of subjects about one product's sustainability (Internal: eco-friendly ingredient vs. External: eco-friendly packaging) by briefing them and introducing phrases such as: "These are organic chocolate chip cookies that are good for the environment" or "These are green packaged cookies that are good for the environment." Subjects rated their ECCB, WTB, and price premium. Moreover, in Study 3, they rated their ECCB preference (five questions; Preference 1-5), product evaluation (four questions; PE 1-4, [44]), satisfaction (three questions; Sat 1-3) [45], weekly average frequency of snack (or cookie) intake, and favorite cookie flavor. All variables were measured with on a five-point Likert scale ranging from 1 ("Strongly Disagree") to 5 ("Strongly Agree"). At the end of the experiment, we debriefed subjects regarding the actual purpose of the experiment. After the experiment, all subjects were rewarded with three dollars for participation. 


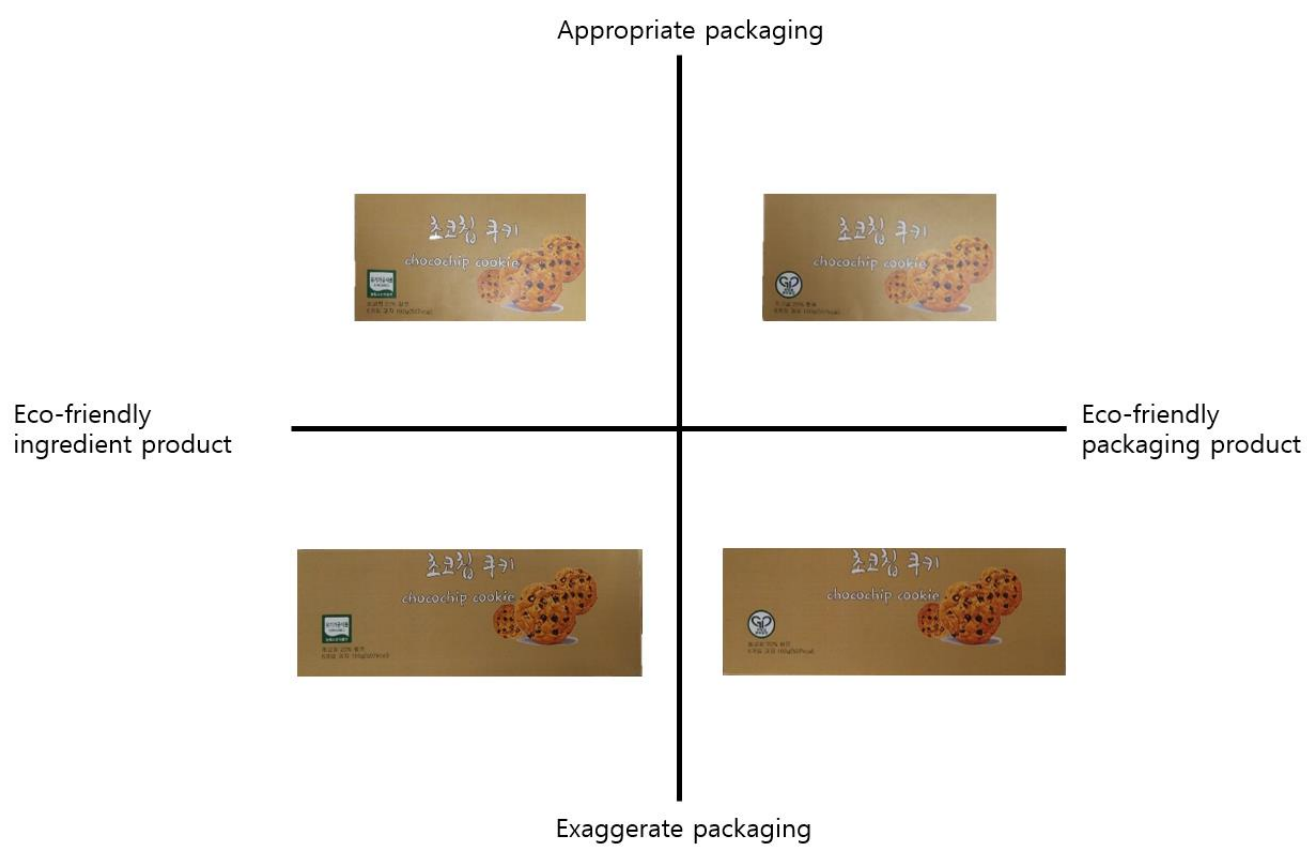

Figure 7. Experimental design of Study 3.

There were 112 undergraduate students who participated (71 male and 41 female). We checked the convergent validity and the discriminant validity of constructs in Study 2. Tables 7 and 8 show that our measurement model demonstrates sufficient convergent validity and discriminant validity.

Table 7. The results of the convergent validities: Loadings among measures.

\begin{tabular}{|c|c|c|c|c|c|c|}
\hline Latent Variables & Items & $\begin{array}{l}\text { Factor } \\
\text { Loading }\end{array}$ & $\begin{array}{l}\text { Standard } \\
\text { Error }\end{array}$ & $t$-Statistic & $\begin{array}{l}\text { Composite } \\
\text { Reliability }\end{array}$ & AVE \\
\hline \multirow{4}{*}{ Willingness to Buy (WTB) } & WTB1 & 0.823 & 0.037 & 22.516 & \multirow[t]{4}{*}{0.903} & \multirow[t]{4}{*}{0.708} \\
\hline & WTB2 & 0.794 & 0.040 & 19.993 & & \\
\hline & WTB3 & 0.836 & 0.030 & 27.477 & & \\
\hline & WTB4 & 0.909 & 0.015 & 62.544 & & \\
\hline \multirow{3}{*}{ Preference (Pr) } & Pr3 & 0.781 & 0.041 & 19.283 & \multirow[t]{3}{*}{0.814} & \multirow[t]{3}{*}{0.594} \\
\hline & $\operatorname{Pr} 4$ & 0.775 & 0.045 & 17.347 & & \\
\hline & $\operatorname{Pr} 5$ & 0.756 & 0.047 & 16.147 & & \\
\hline \multirow{3}{*}{ Product Evaluation (PE) } & PE2 & 0.746 & 0.054 & 13.778 & \multirow[t]{3}{*}{0.814} & \multirow[t]{3}{*}{0.595} \\
\hline & PE3 & 0.699 & 0.064 & 10.992 & & \\
\hline & PE4 & 0.860 & 0.030 & 28.358 & & \\
\hline \multirow{3}{*}{ Satisfaction (Sat) } & Sat1 & 0.880 & 0.022 & 40.886 & \multirow[t]{3}{*}{0.877} & \multirow[t]{3}{*}{0.704} \\
\hline & Sat2 & 0.890 & 0.017 & 53.813 & & \\
\hline & Sat3 & 0.740 & 0.056 & 13.242 & & \\
\hline \multirow{3}{*}{$\begin{array}{c}\text { Ecologically Conscious } \\
\text { Consumer Behavior } \\
\text { (ECCB) }\end{array}$} & ECCB2 & 0.761 & 0.042 & 18.094 & \multirow[t]{3}{*}{0.866} & \multirow[t]{3}{*}{0.684} \\
\hline & ECCB4 & 0.877 & 0.024 & 36.398 & & \\
\hline & ECCB5 & 0.839 & 0.028 & 29.942 & & \\
\hline
\end{tabular}

Table 8. The results of the convergent validities: Correlation among constructs.

\begin{tabular}{cccccc}
\hline Constructs & WTB & Pr & PE & Sat & ECCB \\
\hline Willingness to Buy (WTB) & $\mathbf{0 . 8 4 1}$ & & & & \\
Preference (Pr) & 0.441 & $\mathbf{0 . 7 7 1}$ & & & \\
Product Evaluation (PE) & 0.586 & 0.173 & $\mathbf{0 . 7 7 1}$ & & \\
Satisfaction (Sat) & 0.798 & 0.457 & 0.548 & $\mathbf{0 . 8 3 9}$ & \\
Ecologically Conscious Consumer Behavior (ECCB) & 0.153 & 0.089 & -0.066 & 0.091 & $\mathbf{0 . 8 2 7}$ \\
\hline
\end{tabular}


Subjects' favorite type of cookie was chocolate chip ( 85 chocolate chip, 11 butter, 10 nut, 5 fruit, and 1 other). On average, subjects eat chips two times a week $(\mathrm{M}=2.29, \mathrm{SD}=1.86)$ and they eat cookies once a week $(\mathrm{M}=1.089, \mathrm{SD}=0.9161)$. In Study 3, all subjects were students, education level was controlled, and two-way ANOVA was conducted. The ECCB rate did not vary among the four independent groups $(F(1,108)=0.003, p=0.955)$. The interaction effect between eco-friendly attributes and packaging level on WTB $\left(F(1,107)=4.747, p=0.032^{2}\right.$, Table 9) and satisfaction (Levene $F(1,108)=5.933, p=0.016^{2}$, Table 10) was significant, but preference $(F(1,108)=0.521, p=0.472)$, product evaluation (Levene $F(1,108)=0.996, p=0.321)$, and price premium $(F(1,108)=0.641, p=0.425)$ were not significant. H5 and H6 about WTB (Figure 8) and satisfaction (Figure 9) were accepted. Two-sample pairwise comparison (including a Bonferroni test) show that organic cookies $(F(1,106)=4.543 p=0.035)$ packaged in an appropriate manner $(\mathrm{N}=27, \mathrm{M}=3.713, \mathrm{SD}=0.739)$ led to higher WTB than those packaged in an exaggerated manner $(\mathrm{N}=25, \mathrm{M}=3.300, \mathrm{SD}=0.718)$. For cookies with eco-friendly packaging, there was no significant difference $(F(1,106)=1.133, p=0.290)$. Nonetheless, exaggerated packaging $(\mathrm{N}=30, \mathrm{M}=3.550, \mathrm{SD}=0.766)$ tended to receive a higher score on WTB than appropriate packaging $(\mathrm{N}=29, \mathrm{M}=3.370, \mathrm{SD}=0.625)$.

Table 9. ANOVA results of Study 3: Willingness to Buy (WTB).

\begin{tabular}{cccc}
\hline Source & df & $\boldsymbol{F}$ & $\boldsymbol{p}$ \\
\hline Intercept & 1 & 2627.05 & 0.000 \\
Sustainable attribute & 1 & 0.739 & 0.392 \\
Level of packaging & 1 & 0.115 & 0.735 \\
Corrected model & 1 & 4.747 & 0.032 \\
Sustainable attribute $\times$ Level of packaging & 3 & 1.806 & 0.15 \\
\hline
\end{tabular}

Table 10. ANOVA results of Study 3: Satisfaction.

\begin{tabular}{cccc}
\hline Source & df & $\boldsymbol{F}$ & $p$ \\
\hline Intercept & 1 & 1706.412 & 0.000 \\
Sustainable attribute & 1 & 1.521 & 0.22 \\
Level of packaging & 1 & 0.077 & 0.782 \\
Sustainable attribute $\times$ Level of packaging & 1 & 5.933 & 0.016 \\
Corrected model & 3 & 2.393 & 0.072 \\
\hline
\end{tabular}

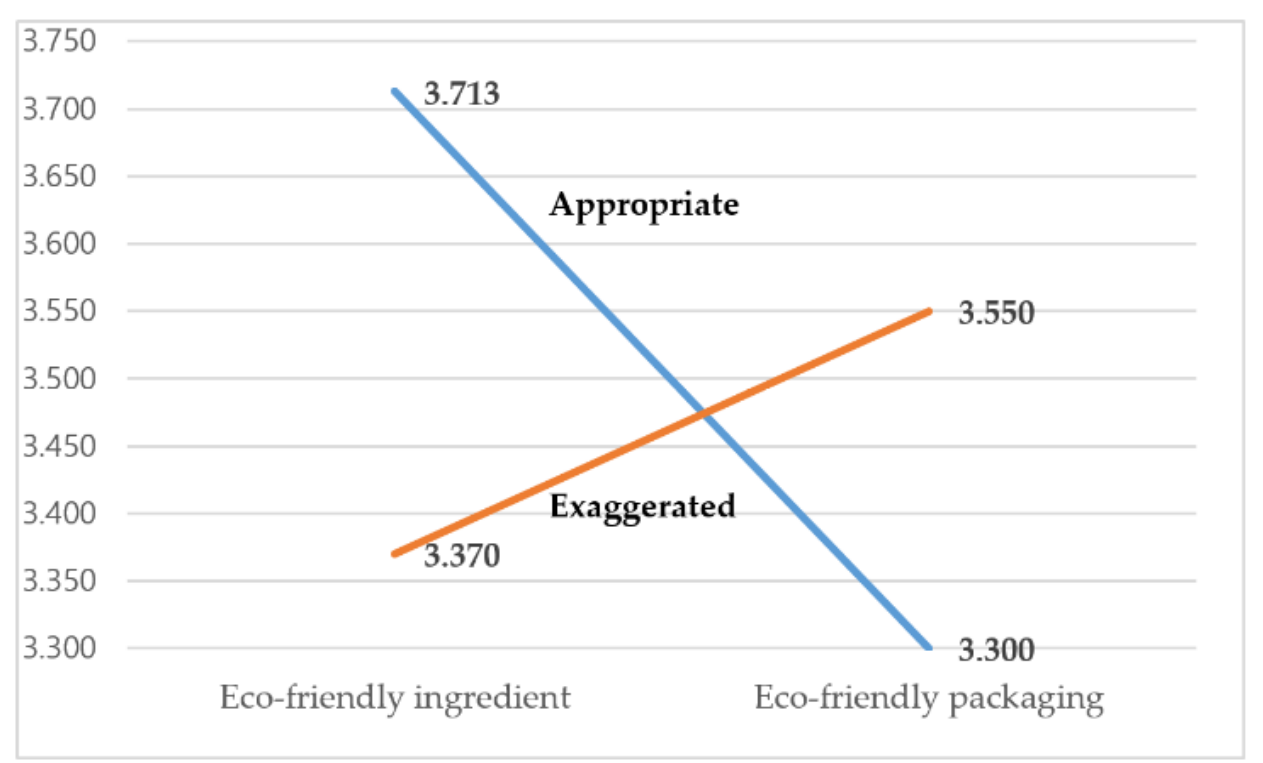

Figure 8. Results of Study 3: Willingness to Buy (WTB). 


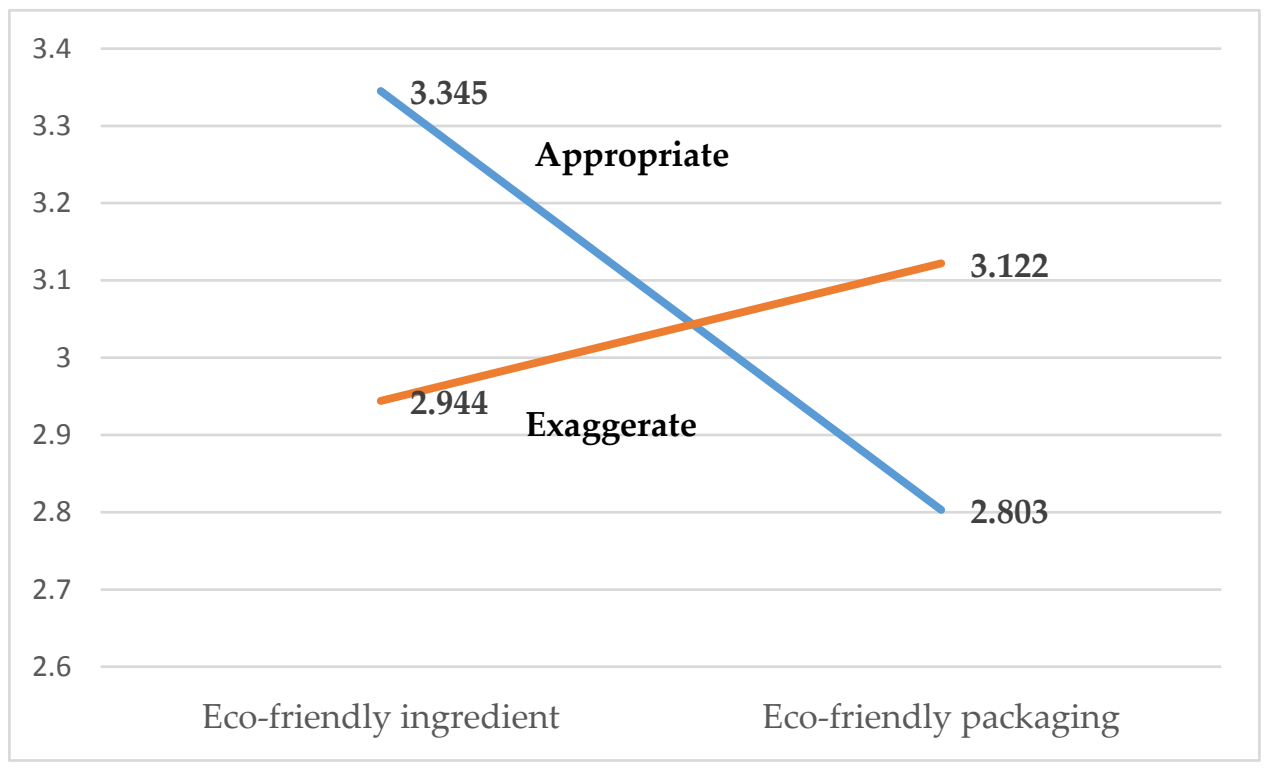

Figure 9. Results of Study 3: Satisfaction.

\section{Discussion}

Through experiments, this study investigated consumers' WTB and price premium for two types of eco-friendly products. The main purpose of Study 1 and Study 2 was to investigate whether the consumers' WTB and price premium for sustainable products would differ based on the product's sustainability attributes (i.e., internal: eco-friendly ingredient-organic vs. external: eco-friendly packaging-green packaging) and product attributes (i.e., utilitarian vs. hedonic, and gentleness-related vs. strength-related).

In summary, the results of both studies (Study 1 and Study 2) indicated that according to eco-friendliness and product attributes, consumers' WTB for product can differ. As expected, consumers have a tendency to prefer eco-friendly ingredient utilitarian products (i.e., organic protein bar) to eco-friendly packaged utilitarian products because consumers tend to consider an eco-friendly ingredient product as healthier than a conventional product. Therefore, because of expectancy confirmation, consumers' WTB rose. Moreover, in this study, we found that consumers' preference for an eco-friendly packaged (eco-friendly packaging) hedonic product (i.e., eco-friendly packed jelly beans) was higher than the preference for an eco-friendly ingredient hedonic product (i.e., eco-friendly ingredient jelly beans). This is because there is a tendency for the eco-friendly ingredient factor (internal attribute of product) to reduce cognitive effectiveness, which is the taste of a product's attributes. As in Study 1, in Study 2, participants had a greater WTB for eco-friendly ingredient (organic, which is the internal eco-friendliness of a product) yogurt (gentleness related product) over eco-friendly packaged (eco-friendly packaging, which is the external eco-friendliness of a product) yogurt because consumers consider organic products to be healthier and safer than conventional ones. In contrast, they had lower evaluations of WTB for eco-friendly ingredient energy drinks (strength related product) than eco-friendly packaged energy drinks because of expectancy disconfirmation. The expectations for energy drinks (strong, powerful, and effective) were not congruent with the expectations for eco-friendly ingredient products.

Moreover, in Study 3, consumers' WTB and price premium for sustainable products differed in accordance with eco-friendliness (internal: ingredients vs. external: packaging) and with packaging level (appropriate vs. excessive). Consumers' WTB for appropriately packaged cookies with eco-friendly ingredients was higher than for those with exaggerated packaging also due to expectancy disconfirmation. The cookies with eco-friendly ingredients that were packaged in an exaggerated manner diminished the participants' confidence (feeling of safety) in the eco-friendly ingredient 
product, which is one of the reasons why consumers buy eco-friendly ingredient food products. Participants' WTB and satisfaction between eco-friendly packaged cookies that are packaged in an exaggerated manner shows higher WTB and satisfaction than appropriate packaging, which can be explained by the cognitive dissonance theory.

\section{Limitations and Implications}

This study has several limitations. First, in Study 2, we did not control the balance of the participants' gender, nor did we assess their daily preference and the frequency of yogurt (vs. energy drink) consumption. Second, in Study 3, all participants were students and the gender balance was not controlled. Third, this study was conducted in a laboratory, and thus there may be some gaps between the actual market and the small sample size analyzed in the laboratory. Fourth, in Study 3 , consumers' attitude towards appropriately or exaggerated non-eco-friendly packaged packaging was not checked. Fifth, we did not check the consumers' WTB and price premium toward products that have both eco-friendly ingredient and eco-friendly packaging. Finally, we used only two stimuli each in Studies 1 and 2, and one stimulus in Study 3. Therefore, we hope that future research will extend this study's results by simultaneously considering other kinds of food products and product attributes.

Currently, the importance of sustainable products is rapidly increasing because of environmental pollution. However, there has been little research into sustainable products and most research with regards to eco-friendly products have been focused on organic products. Therefore, the understanding of consumers' attitude toward sustainable products is still insufficient. This study provided different results from previous studies. In this study, through experimentation, we investigated not only consumers' WTB for different kinds of eco-friendly ingredient products, but also their WTB for different kinds of eco-friendly packaged products. The results of this study have academic and practical implications.

Academically, this study makes several theoretical contributions to the literature. The findings expanded the consequence of consumers' purchasing behavior toward sustainable products. As in previous research $[13,14]$, we conducted an experiment and identified not only consumers' attitudes toward eco-friendly ingredient (organic) or eco-friendly packaged products, but also the interaction effect between a product's attribute and eco-friendliness. By investigating the interaction effect, we found that when the product's attribute is related to hedonic and strength factors, the eco-friendliness of the packaging increases consumers' WTB more than the eco-friendly ingredients. In addition, in Study 3, we found that not only eco-friendliness, but also the level of packaging can influence consumers' WTB. The results of Study 3 enhance the understanding of the effect of packaging, which is the visual element of a product, on consumers' food choices.

Practically, the results of this study have implications for producers. When manufactures develop and update their products, they consider the eco-friendliness of product because of environmental protection and profit maximization. Many kinds of eco-friendly ingredient products exist in the marketplace, and many of them were developed without consideration of the product's own attributes. The results of this study indicated that the utility-related and gentleness-related products should be developed as eco-friendly ingredient rather than as eco-friendly packaged products. The results of this study also indicated that hedonic-related and strength-related products should be developed as eco-friendly packaged rather than as eco-friendly ingredient products. Making and updating products into eco-friendly ingredient product can expend high costs and can risk harming or changing the product's central traits like taste or properties. Therefore, when food producers develop products, they should consider both the eco-friendliness and the product attributes. If using eco-friendly ingredients harm the product's central traits (when expectancy disconfirmation occurs), using eco-friendly packaging as an alternative to using eco-friendly ingredients can help protect the environment and maximize profits. Moreover, producers hesitate to update conventional products to sustainable products, as mentioned above, because using eco-friendly ingredients can harm the products' central trait. However, eco-friendly packaging is an external attribute of the products; therefore updating 
conventional product with eco-friendly packaging can be a solution. However, commonly, most eco-friendly packaged products in the marketplace appear as recycled cardboard. Therefore, producers hesitate to update conventional products to eco-friendly packaged ones because change in the visual cues of products can harm the products' identity. Through Studies 1 and 2, we found that information about the eco-friendliness of packaging informed by certification can increase consumers' WTB. Therefore, updating conventional products' packaging to eco-friendly packaging that is certified with no changes in visual cues is one potential solution. In addition, when designing packaging, companies should consider how the level of packaging influences sales. The visual cues of products informed by packaging primarily affect consumers' product evaluation. When it comes to packaging, highly valued organic products need more consideration in terms of packaging level because excessive packaging can harm the products' evaluation. Excessive packaging also diminishes consumers' confidence of product. When it is necessary to use buffer packaging, companies should consider eco-friendly packaging to maximize revenue, consumers' satisfaction, and environmental protection. These developments will increase consumers' WTB for sustainable products and will have positive effects on environmental protection and product revenues. Furthermore, these actions will help promote the implementation of corporate accountability and improve the company's public image. If sustainable attributes have a negative effect on products, they can harm the product's brand identity.

Acknowledgments: This research was supported by the MSIP (Ministry of Science, ICT and Future Planning), Korea, under the ITRC (Information Technology Research Center) support program (IITP-2016-H8601-16-1007) supervised by the IITP (Institute for Information \& communications Technology Promotion). This work was carried out with the support of "Cooperative Research Program for Agriculture Science \& Technology Development (Project No. PJ01139001)" Rural Development Administration, Republic of Korea.

Author Contributions: All of the authors made contributions to the work in this paper. Soyoung Seo, Hee-Kyung Ahn, Junghoon Moon and Jaeseok Jeong designed the experiments; Soyoung Seo and Junghoon Moon developed the methodology; Soyoung Seo, Junghoon Moon and Hee-Kyung Ahn collected the data; Soyoung Seo, Hee-Kyung Ahn and Junghoon Moon performed the analysis; Soyoung Seo wrote the paper.

Conflicts of Interest: The authors declare no conflict of interest.

\section{References}

1. Mazar, N.; Zhong, C.-B. Do green products make us better people? Psychol. Sci. 2010. [CrossRef] [PubMed]

2. Grankvist, G.; Dahlstrand, U.; Biel, A. The impact of environmental labelling on consumer preference: Negative vs. Positive labels. J. Consum. Policy 2004, 27, 213-230. [CrossRef]

3. Botonaki, A.; Polymeros, K.; Tsakiridou, E.; Mattas, K. The role of food quality certification on consumers' food choices. Br. Food J. 2006, 108, 77-90. [CrossRef]

4. Magnier, L.; Schoormans, J.; Mugge, R. Judging a product by its cover: Packaging sustainability and perceptions of quality in food products. Food Qual. Preference 2016, 53, 132-142. [CrossRef]

5. Chen, M.-F. Consumer attitudes and purchase intentions in relation to organic foods in taiwan: Moderating effects of food-related personality traits. Food Qual. Preference 2007, 18, 1008-1021. [CrossRef]

6. Ophuis, P.A.O.; Van Trijp, H.C. Perceived quality: A market driven and consumer oriented approach. Food Qual. Preference 1995, 6, 177-183. [CrossRef]

7. Grankvist, G.; Biel, A. The importance of beliefs and purchase criteria in the choice of eco-labeled food products. J. Environ. Psychol. 2001, 21, 405-410. [CrossRef]

8. Hughner, R.S.; McDonagh, P.; Prothero, A.; Shultz, C.J.; Stanton, J. Who are organic food consumers? A compilation and review of why people purchase organic food. J. Consum. Behav. 2007, 6, 94-110. [CrossRef]

9. Wilkins, J.L.; Hillers, V.N. Influences of pesticide residue and environmental concerns on organic food preference among food cooperative members and non-members in washington state. J. Nutr. Educ. 1994, 26, 26-33. [CrossRef]

10. Zanoli, R.; Naspetti, S. Consumer motivations in the purchase of organic food: A means-end approach. Br. Food J. 2002, 104, 643-653. [CrossRef]

11. Laroche, M.; Bergeron, J.; Barbaro-Forleo, G. Targeting consumers who are willing to pay more for environmentally friendly products. J. Consum. Mark. 2001, 18, 503-520. [CrossRef] 
12. Sörqvist, P.; Hedblom, D.; Holmgren, M.; Haga, A.; Langeborg, L.; Nöstl, A.; Kågström, J. Who needs cream and sugar when there is eco-labeling? Taste and willingness to pay for "eco-friendly" coffee. PLoS ONE 2013, 8, e80719. [CrossRef] [PubMed]

13. Luchs, M.G.; Naylor, R.W.; Irwin, J.R.; Raghunathan, R. The sustainability liability: Potential negative effects of ethicality on product preference. J. Mark. 2010, 74, 18-31. [CrossRef]

14. Lee, W.-C.J.; Shimizu, M.; Kniffin, K.M.; Wansink, B. You taste what you see: Do organic labels bias taste perceptions? Food Qual. Preference 2013, 29, 33-39. [CrossRef]

15. Schuldt, J.P.; Hannahan, M. When good deeds leave a bad taste. Negative inferences from ethical food claims. Appetite 2013, 62, 76-83. [CrossRef] [PubMed]

16. McCarty, J.A.; Shrum, L. The recycling of solid wastes: Personal values, value orientations, and attitudes about recycling as antecedents of recycling behavior. J. Bus. Res. 1994, 30, 53-62. [CrossRef]

17. Ampuero, O.; Vila, N. Consumer perceptions of product packaging. J. Consum. Mark. 2006, 23, $100-112$. [CrossRef]

18. Min, H.; Galle, W.P. Green purchasing strategies: Trends and implications. J. Supply Chain Manag. 1997, 33, 10. [CrossRef]

19. Rokka, J.; Uusitalo, L. Preference for green packaging in consumer product choices-do consumers care? Int. J. Consum. Stud. 2008, 32, 516-525. [CrossRef]

20. Magnier, L.; Schoormans, J. Consumer reactions to sustainable packaging: The interplay of visual appearance, verbal claim and environmental concern. J. Environ. Psychol. 2015, 44, 53-62. [CrossRef]

21. Tobler, C.; Visschers, V.H.; Siegrist, M. Eating green. Consumers' willingness to adopt ecological food consumption behaviors. Appetite 2011, 57, 674-682. [CrossRef] [PubMed]

22. Silayoi, P.; Speece, M. Packaging and purchase decisions: An exploratory study on the impact of involvement level and time pressure. Br. Food J. 2004, 106, 607-628. [CrossRef]

23. Ares, G.; Piqueras-Fiszman, B.; Varela, P.; Marco, R.M.; López, A.M.; Fiszman, S. Food labels: Do consumers perceive what semiotics want to convey? Food Qual. Prefer. 2011, 22, 689-698. [CrossRef]

24. Rettie, R.; Brewer, C. The verbal and visual components of package design. J. Product Brand Manag. 2000, 9 , 56-70. [CrossRef]

25. Rigby, D.; Cáceres, D. Organic farming and the sustainability of agricultural systems. Agric. Syst. 2001, 68, 21-40. [CrossRef]

26. Lampkin, N.; Padel, S.; Foster, C.; Brouwer, F.; Lowe, P. Organic Farming; CABI Publishing: Oxfordshire, UK, 2000.

27. Olson, J.C.; Jacoby, J. In Cue utilization in the quality perception process. In SV-Proceedings of The Third Annual Conference of the Association for Consumer Research; Association for Consumer Research: Chicago, IL, USA, 1972.

28. Svanes, E.; Vold, M.; Møller, H.; Pettersen, M.K.; Larsen, H.; Hanssen, O.J. Sustainable packaging design: A holistic methodology for packaging design. Packag. Technol. Sci. 2010, 23, 161-175. [CrossRef]

29. Marsh, K.; Bugusu, B. Food packaging_Roles, materials, and environmental issues. J. Food Sci. 2007, 72, R39-R55. [CrossRef] [PubMed]

30. Underwood, R.L. The communicative power of product packaging: Creating brand identity via lived and mediated experience. J. Mark. Theory Pract. 2003, 11, 62-76. [CrossRef]

31. Oliver, R.L. A cognitive model of the antecedents and consequences of satisfaction decisions. J. Mark. Res. 1980, 460-469. [CrossRef]

32. Wandel, M.; Bugge, A. Environmental concern in consumer evaluation of food quality. Food Qual. Preference 1997, 8, 19-26. [CrossRef]

33. Cramer, L.; Antonides, G. Endowment effects for hedonic and utilitarian food products. Food Qual. Preference 2011, 22, 3-10. [CrossRef]

34. Dhar, R.; Wertenbroch, K. Consumer choice between hedonic and utilitarian goods. J. Mark. Res. 2000, 37, 60-71. [CrossRef]

35. Hirschman, E.C.; Holbrook, M.B. Hedonic consumption: Emerging concepts, methods and propositions. J. Mark. 1982, 46, 92-101. [CrossRef]

36. Dodds, W.B. In search of value: How price and store name information influence buyers' product perceptions. J. Consum. Market. 1991, 8, 15-24. [CrossRef] 
37. Aaker, D.A. Measuring brand equity across products and markets. Calif. Manag. Rev. 1996, 38, $102-120$. [CrossRef]

38. Festinger, L. A Theory of Cognitive Dissonance; Stanford University Press: Redwood City, CA, USA, 1962; Volume 2.

39. Voss, K.E.; Spangenberg, E.R.; Grohmann, B. Measuring the hedonic and utilitarian dimensions of consumer attitude. J. Mark. Res. 2003, 40, 310-320. [CrossRef]

40. Samdahl, D.M.; Robertson, R. Social determinants of environmental concern specification and test of the model. Environ. Behavior 1989, 21, 57-81. [CrossRef]

41. Fornell, C.; Larcker, D.F. Evaluating structural equation models with unobservable variables and measurement error. J. Mark. Res. 1981, 18, 39-50. [CrossRef]

42. Chin, W.W. The partial least squares approach to structural equation modeling. Modern Methods Bus. Res. 1998, 295, 295-336.

43. Kang, C.; Hwang, Y.; Moon, J. Informationization of small-scale agribusinesses in rural areas of korea perspectives from institutional theory. Inf. Dev. 2015. [CrossRef]

44. Juhl, H.J.; Kristensen, K.; Østergaard, P. Customer satisfaction in european food retailing. J. Retail. Consum. Serv. 2002, 9, 327-334. [CrossRef]

45. McEachern, M.; Seaman, C.; Padel, S.; Foster, C. Exploring the gap between attitudes and behaviour: Understanding why consumers buy or do not buy organic food. Br. Food J. 2005, 107, 606-625.

(C) 2016 by the authors; licensee MDPI, Basel, Switzerland. This article is an open access article distributed under the terms and conditions of the Creative Commons Attribution (CC-BY) license (http:/ / creativecommons.org/licenses/by/4.0/). 